\title{
Nutritional Management in Childhood Obesity
}

\author{
Jieun Kim', Hyunjung Lim ${ }^{1,2, *}$ \\ ${ }^{1}$ Research Institute of Medical Nutrition, Kyung Hee University, Seoul, ${ }^{2}$ Department of Medical Nutrition, Graduate School of East-West Medical Science, Kyung Hee \\ University, Yongin, Korea
}

The increasing prevalence of overweight and obese children and adolescents poses a major concern worldwide. Dietary practice in these critical periods affects physical and cognitive development and has consequences in later life. Therefore, acquiring healthy eating behaviors that will endure is important for children and adolescents. Nutrition management has been applied to numerous childhood obesity intervention studies. Diverse forms of nutrition education and counseling, key messages, a Mediterranean-style hypocaloric diet, and nutritional food selection have been implemented as dietary interventions. The modification of dietary risk in terms of nutrients, foods, dietary patterns, and dietary behaviors has been applied to changing problematic dietary factors. However, it is not easy to identify the effectiveness of nutritional management because of the complex and interacting components of any multicomponent approach to intervention in childhood obesity. In this review, we describe the modifiable dietary risk factors and nutritional components of previous nutrition intervention studies for nutritional management in childhood obesity. Furthermore, we suggest evidence-based practice in nutrition care for obese children and adolescents by considering obesity-related individual and environmental dietary risk factors.

Key words: Pediatric obesity, Nutrition therapy, Diet therapy

\author{
Received October 20, 2019 \\ Reviewed November 13, 2019 \\ Accepted December 9, 2019 \\ ${ }^{*}$ Corresponding author \\ Hyunjung Lim \\ https://orcid.org/0000-0001-7632-7315 \\ Department of Medical Nutrition, \\ Graduate School of East-West Medical \\ Science, Kyung Hee University, 1732 \\ Deogyeong-daero, Giheung-gu, Yongin \\ 17104, Korea \\ Tel: +82-31-201-2343 \\ Fax: +82-2-969-7717 \\ E-mail: hjlim@khu.ac.kr
}

\section{INTRODUCTION}

The childhood obesity epidemic has reached 124 million individuals, and nearly one in five children and adolescents are overweight or obese. ${ }^{1}$ The worldwide trend in childhood obesity shows a steadily increasing body mass index (BMI) in children and adolescents across four decades. In East and South Asia, including South Korea, the BMI increase among children and adolescents has accelerated since $2000 .^{2}$ The prevalence of obesity in children and adolescents increased from $11.6 \%$ in 2008 to $17.3 \%$ in $2017 .{ }^{3}$ Obesity in early life is of concern due to health consequences and its influence on later life. ${ }^{4}$ Increased adiposity levels are strongly associated with developing metabolic disorders and signs of adverse cardiometabolic diseases. ${ }^{5}$ The severity of these comorbidities typically increases with the severity of the obesity. ${ }^{6}$

Dietary- and health-related behaviors and food preferences are established in early childhood and continue into adulthood. ${ }^{7}$ Poor food choices and overconsumption are associated with a higher risk of developing obesity. ${ }^{8}$ The prevalence of diet-related metabolic disorders such as obesity, glucose intolerance, elevated blood pressure, and dyslipidemia is increasing due to unbalanced food intake among adolescents. ${ }^{9}$ Dietary factors are the most important factors associated with childhood obesity, ${ }^{10}$ and prevalence rates of nutrition-related noncommunicable diseases such as obesity and diabetes in children and adolescents have prompted prioritizing healthy diets. ${ }^{1}$

Dietary intervention and multisectoral approach intervention studies have reported positive changes in body composition and dietary factors for overweight and obese children and adolescents. ${ }^{11-16}$ Dietary components such as energy-dense foods, sugarsweetened beverages (SSBs) and patterns of processed food consumption are discussed among the modifiable risk factors associat- 
ed with obesity in children and adolescents. ${ }^{17-19}$ In the present review, we describe the dietary risk factors associated with childhood obesity and summarize the previous efforts at nutrition management in multisectoral interventions. In addition, we suggest customized nutrition care for obese children and adolescents to improve young children's dietary factors.

\section{DIETARY RISK FACTORS IN CHILDHOOD OBESITY}

Numerous diet-related modifiable risk factors (nutrients, foods, dietary patterns, and eating behaviors) have been considered in previous clinical research studies and suggested in guidelines on childhood obesity (Table 1). A higher intake of saturated fats and carbohydrates, including the overconsumption of energy-dense foods such as pizza, soda, and SSBs, has been associated with obesity in children and adolescents. ${ }^{20,21}$ Dietary patterns during childhood have identified associations between diet and diseases such as diabetes, hypertension, cardiometabolic risk, and childhood obesity. ${ }^{4,18,22}$ The Western dietary pattern, which contains high amounts of saturated fatty acids, is energy-dense, is micronutrient poor, and is limited in non-starch polysaccharides (fiber), is known to be a dietary risk factor encouraging childhood obesity. ${ }^{17,23}$ Diet patterns that are rich in meat, soda, fried food, instant noodles, burgers, and pizza increased the risk of obesity by $30 \%$ compared to diet patterns rich in whole grains, legumes, potatoes, fish, mushrooms, seaweed, fruits, and vegetables. ${ }^{24}$

Unhealthy eating habits and patterns formed during childhood have been associated with nutrition-related noncommunicable diseases such as obesity and diabetes. ${ }^{25}$ Sedentary behavior among children and adolescents, higher intake of snacks, consumption of SSBs, fast food consumption, eating while watching television, skipping breakfast, reduced numbers of family meal times spent eating together, and lower daily intake of milk, fruits, and vegetables have all been associated with increased rates of childhood obesity, leading to adverse health and dietary outcomes. ${ }^{26,27}$

Meanwhile, an adequate nutritional intake of vitamins and minerals, whole grains, milk and dairy products, fruits, and vegetables in a balanced diet has been found to not only protect growth but also manage childhood obesity. ${ }^{17,28-31}$ In addition, it is recommended that proper dietary behaviors with family support include meals at home, eating together as a family, regular mealtimes, and portion sizes appropriate for the daily requirements of children and adolescents. ${ }^{19,32,33}$

\section{NUTRITION-BASED MULTIDISCIPLINARY INTERVENTION COMPONENTS AFFECTING CHILDHOOD OBESITY}

Systematic reviews have suggested that multiple strategies and components and a multilevel approach that focuses on diet and health-related activities have provided the most sustainable and beneficial effects on childhood obesity intervention, rather than single-component interventions. ${ }^{34,35}$ Furthermore, social support such as individualized coaching, text messaging, face-to-face communication, and Internet-based approaches with a theoretical back-

Table 1. Diet-related modifiable factors affecting childhood obesity

\begin{tabular}{|c|c|c|}
\hline Factor & Harmful & Beneficial \\
\hline Nutrient & $\begin{array}{l}\text { - Excessive intake of total energy, proteins (from animal products), } \\
\text { fat, saturated fat, sodium } 17,28\end{array}$ & $\begin{array}{l}\text { - Adequate intake of vitamins C and D, non-starch polysaccharides } \\
\text { (fiber), calcium, folate, iron }{ }^{17,29,36}\end{array}$ \\
\hline Food & $\begin{array}{l}\text { - Excessive intake of energy-dense foods: pizza, fast food, discretionary } \\
\text { food, soda, sugar-sweetened beverages, and ice cream²3,27,34 }\end{array}$ & $\begin{array}{l}\text { - Adequate intake of whole grains }{ }^{30,31} \\
\text { - Low daily consumption of milk, fruits, vegetables, fish }{ }^{37,38}\end{array}$ \\
\hline Dietary pattern & $\begin{array}{l}\text { - Westernized dietary patterns high in saturated fatty acids, dense in } \\
\text { energy, and poor in micronutrients } 17,18,23 \\
\text { - Processed food dietary patterns, including meat, soda, fried food, } \\
\text { instant noodles, burgers, and pizza }{ }^{24}\end{array}$ & $\begin{array}{l}\text { - Balanced diet based on five food groups }{ }^{17,28-31} \\
\text { - Stop-light/traffic-light diet, with food divided into three categories: } \\
\text { green (low-energy, high-nutrient foods), yellow (moderate-energy } \\
\text { foods), and red (high-energy, low-nutrient foods) }\end{array}$ \\
\hline Dietary behaviors and eating habits & $\begin{array}{l}\text { - Eating while watching TV } \\
\text { - Skipping breakfast }{ }^{26,27} \\
\text { - Frequent snacking and eating }{ }^{19}\end{array}$ & $\begin{array}{l}\text { - Family mealtimes, eating together }{ }^{19,32} \\
\text { - Portion control } \\
\text { - Regular mealtimes } \\
\text { - Re,32,33 }\end{array}$ \\
\hline
\end{tabular}

Guidelines and recommendations ${ }^{17-19,23,24,26-34,36-40}$ of diet-related modifiable factors for nutritional management in childhood obesity. 
ground have been adapted to change obesity-related dietary behaviors in children and adolescents. ${ }^{12-16,41-43}$ The most promising approaches for childhood obesity management are intervening with support at levels ranging from individual to community via sustainable and multisectoral strategies. ${ }^{44}$

Let's Move was a program of the U.S. government in collaboration with the American Academy of Pediatrics intended to provide Internet-based resources for BMI and diet and to develop activity screening in primary care, including counseling and advocacy methods for healthcare professionals. ${ }^{11}$ Consistent with this initiative, innovative use of health information technology was implemented via individualized coaching for behavior change, ${ }^{12}$ text messaging to provide outreach support for obesity management, ${ }^{41}$ and study-specific website and email programs, which had achievements similar to those found with face-to-face support. ${ }^{42}$

The B'More Healthy Communities for Kids trial was a multilevel childhood obesity prevention intervention guided by social cognitive theory, social ecology, and systems theory. According to these theories, psychosocial factors, social-environmental factors, and physical factors interact at multiple levels to shape health-related outcomes. ${ }^{13}$ In this study, wholesalers, corner stores, take-out restaurants, recreation centers, and households worked together to improve availability, purchasing, and consumption of healthier foods and beverages (low sugar, low fat) in low-income African American zones in the city of Baltimore, MD, USA. ${ }^{13}$

The Childhood Obesity Demonstration (CORD) project was designed to cover 4 years, including three grantees, Massachusetts (MA CORD), California (CA CORD), and Texas (TX CORD), funded by the Centers for Disease Control and Prevention. ${ }^{14}$ This set of three unique multilevel, multi-setting demonstration projects aimed to prevent childhood obesity by supporting healthy eating and active living among 2- to 12-year-old children. The results from the MA CORD study included changes in organizational policies and environments to better support healthy living and improvements in health behaviors of children, parents, and stakeholders. ${ }^{15}$

The identification and prevention of dietary- and lifestyle-induced health effects in children and infants (IDEFICS) study was developed by eight European countries to implement and evaluate diet- and lifestyle-related diseases and was strongly focused on childhood obesity in a large population-based cohort of 16,228 Eu- ropean children aged 2 to 9 years. ${ }^{16}$ The IDEFICS intervention focused on the three main concepts of nutrition, physical activity, and stress, and it formulated six key messages. The prospective study reported that children consistently allocated to the "processed" cluster increased their BMI, waist circumference, and fat mass gain compared to children allocated to the "healthy" cluster. Being in the "processed"-"sweet" cluster combination was also linked to increased BMI, waist circumference, and fat mass gain over time compared to the "healthy" cluster. ${ }^{43}$

\section{RECENT DIETARY INTERVENTIONS AND OUTCOMES}

We performed a systematic review of the literature for identifying the effectiveness of nutritional interventions using the electronic databases PubMed, Cochrane Library, and Web of Science, covering the past 5 years (2015 through August 2019). The following search terms were used: childhood obesity, obese children and adolescents, nutritional intervention, and dietary outcomes. Trials published in English were included in this study; the primary outcomes examined were energy, nutrient intake, fruit and vegetable consumption, and dietary behaviors.

\section{Dietary interventions}

Only articles on dietary outcomes were extracted from the databases by two researchers. Six studies ${ }^{45-50}$ are summarized in Table 2 among the dietary intervention studies that were selected by titles and abstracts. Nutritional components (nutrition education, key messages, Mediterranean-style hypocaloric diet, and nutritional food selection) and outcomes (energy and nutrient intake; fruit, vegetable, and dairy product consumption; and dietary behaviors) of the dietary intervention studies are presented in Table 2.

Nutrition education was delivered by health instructors at selected schools. Face-to-face training was used, with a book for guidance when necessary, for weekly nutrition sessions for the participants. Monthly lifestyle education sessions focusing on childhood obesity and its causes, cooking methods, and plans to reduce inactivity were provided to parents of the participants. ${ }^{45}$ Curtin University's Activity, Food and Attitudes Program (CAFAP) study focused on healthy food choices and key messages: eat more fruit; 
eat more vegetables; and eat less junk food. Regarding general nutritional themes, energy balance, food labeling, diet variety, fast food, lunchbox food, portion size, and recipe modification were the key topics reinforced in each session, delivered in 12 group education sessions with parents and adolescents together. Parents took part in nutritional sessions and in practical training in shopping at a

Table 2. Changes in dietary factors and weight status of children and adolescents after participating in nutritional interventions

\begin{tabular}{|c|c|c|c|c|c|}
\hline Study & Subject & Duration & Intervention & Nutritional component & Outcome* \\
\hline $\begin{array}{l}\text { Amini et al. } \\
(2016)^{45}\end{array}$ & $\begin{array}{l}(\mathrm{n}=334) \\
\text { Fourth to sixth } \\
\text { grades, } \\
\text { overweight } \\
\text { or obese, } \\
\text { based on } \\
\text { World Health } \\
\text { Organization } \\
\text { standards }\end{array}$ & $18 w k$ & $\begin{array}{l}\text { Nutrition education and } \\
\text { increased PA for the pupils, } \\
\text { lifestyle modification for the } \\
\text { parents, and changes in food } \\
\text { items sold at the schools' } \\
\text { cafeterias. }\end{array}$ & $\begin{array}{l}\text { (1) Provided face-to-face training, the book } \\
\text { General Knowledge of Nutrition whenever } \\
\text { necessary, and a guide for health } \\
\text { instructors; } 15 \text { to } 45 \text { minutes, once a } \\
\text { week; } 12 \text { weekly sessions; concepts of } \\
\text { overweight and obesity, food groups } \\
\text { and energy, and obesogenic situations } \\
\text { and strategies to overcome them } \\
\text { (2) No nutrition education }\end{array}$ & Only the intervention reduced BMl z-score \\
\hline $\begin{array}{l}\text { Smith et al. } \\
(2015)^{46}\end{array}$ & $\begin{array}{l}(\mathrm{n}=69) \\
\text { Aged } 11-16 \\
\text { years, a BMl } \\
\text { for age and } \\
\text { sex above } \\
\text { the 85th } \\
\text { percentile }\end{array}$ & $\begin{array}{l}8 \text { wk (follow-up } \\
12 \text { mo) }\end{array}$ & $\begin{array}{l}\text { Twice-weekly group sessions } \\
\text { at local community site } \\
\text { (CAFAP) targeting the PA, } \\
\text { sedentary behavior, and } \\
\text { healthy eating behaviors of } \\
\text { overweight adolescents }\end{array}$ & $\begin{array}{l}12 \text { Group education sessions with parents } \\
\text { and adolescents together regarding } \\
\text { general nutrition, energy balance, food } \\
\text { labeling, diet variety, fast food, lunchbox } \\
\text { food, portion size, and recipe modification, } \\
\text { with the key messages reinforced in } \\
\text { each session; cooking classes focusing } \\
\text { on the preparation of healthy foods } \\
\text { containing fruits and vegetables }\end{array}$ & $\begin{array}{l}\text { Energy intake }(\mathrm{kJ}) \uparrow \text {, protein }(\mathrm{g}) \uparrow \text {, fat }(\mathrm{g}) \uparrow \text {, } \\
\text { saturated fat }(\mathrm{g}) \downarrow \text {, carbohydrate }(\mathrm{g}) \downarrow \text {, } \\
\text { sugar }(\mathrm{g}) \downarrow \text {, fiber }(\mathrm{g}) \uparrow \\
\text { Self-reported eating behaviors } \uparrow \\
\text { Frequency of breakfast } \downarrow \text {, frequency of fast } \\
\text { food } \downarrow \text {, frequency of sweetened } \\
\text { beverages } \downarrow \text {, perceived daily fruit } \\
\text { servings } \uparrow \text {, perceived daily } \\
\text { Vegetable servings } \uparrow\end{array}$ \\
\hline $\begin{array}{l}\text { Serra-Paya et al. } \\
(2015)^{49}\end{array}$ & $\begin{array}{l}(n=113) \\
\text { Aged } \\
\text { 6-12 years, } \\
\text { overweight } \\
\text { or obese }\end{array}$ & $8 \mathrm{mo}$ & $\begin{array}{l}\text { (1) Family-based } \\
\text { multicomponent behavioral } \\
\text { intervention } \\
\text { (2) Usual advice from their } \\
\text { pediatrician on healthy } \\
\text { eating and PA }\end{array}$ & $\begin{array}{l}\text { Three behavior strategy sessions were } \\
\text { designed to reinforce the acquisition of } \\
\text { healthier PA and eating habits within the } \\
\text { family. }\end{array}$ & 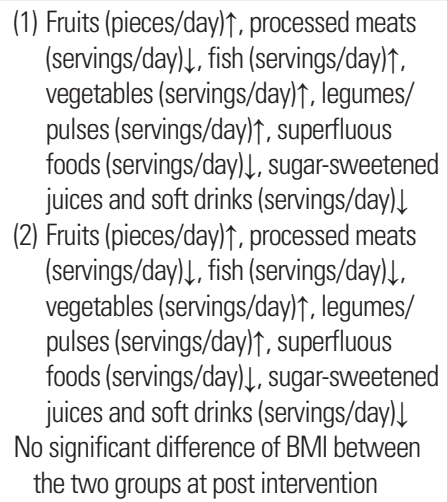 \\
\hline
\end{tabular}


Table 2. Continued

\begin{tabular}{|c|c|c|c|c|c|}
\hline Study & Subject & Duration & Intervention & Nutritional component & Outcome* \\
\hline $\begin{array}{l}\text { Llauradó et al. } \\
(2018)^{50}\end{array}$ & $\begin{array}{l}\text { (n=349) } \\
\text { 13- to } \\
\text { 15-year-old } \\
\text { adolescents } \\
\text { with } \\
\text { childhood } \\
\text { obesity }\end{array}$ & 4-yr follow-up & $\begin{array}{l}\text { Twelve educational } \\
\text { intervention activities that } \\
\text { focused on eight lifestyle } \\
\text { topics selected based on } \\
\text { scientific evidence to } \\
\text { improve nutritional food } \\
\text { selection, healthy habits, } \\
\text { and overall adoption of } \\
\text { behaviors that encourage PA }\end{array}$ & $\begin{array}{l}\text { (1) To encourage the intake of healthy } \\
\text { drinks (and the avoidance of unhealthy } \\
\text { carbonated sweetened beverages) } \\
\text { (2) To increase the consumption of } \\
\text { vegetables and legumes } \\
\text { (3) To decrease the consumption of } \\
\text { candies and pastries while increasing } \\
\text { the intake of fresh fruits and nuts } \\
\text { (second year) } \\
\text { (4) To increase fruit intake } \\
\text { (5) To improve dairy product consumption } \\
\text { and to increase fish consumption }\end{array}$ & $\begin{array}{l}\text { Only the intervention girls showed reduced } \\
\text { BMl z-scores. }\end{array}$ \\
\hline
\end{tabular}

*Outcomes: (after the intervention) $\uparrow$ : increase, $\downarrow$ : decrease.

PA: physical activity; BMI, body mass index; CAFAP: Curtin University's Activity, Food and Attitudes Program.

supermarket and cooking classes for healthy foods such as fruits and vegetables. ${ }^{46}$

The Intervention Grupo Navarro de Estudio de la Obe- sidad Infantil study consisted of an 8-week phase and a 2-year follow-up program. The usual care group received standard pediatric recommendations and anthropometric measurements, while the intensive care group was advised to adhere to a Mediterranean-style hypocaloric diet. Nutritional theme-based topics included controlling healthy lifestyle behavior, food preparation, portion control, eating behavior, food composition, and the importance of being physically active during leisure time. In addition, information on healthy lifestyles and how to manage obesity-related problems was provided to the caregivers by dietitians. ${ }^{48}$

The Nereu Program (NP) was an intensive, 8-month, familybased, multicomponent behavioral intervention on healthy eating and physical activity in 6- to 12-year-old children who were overweight and obese. The NP consisted of the following four components: physical activity, family theoretical and practical training for parents, a behavioral component for both children and parents, and activities. For the usual treatment group, a 10-minute monthly family meeting based on the same NP components was provided over an 8-month period. Based on the food frequency questionnaire and main nutritional characteristics, the intervention addressed the following foods for participants and their families: all fruits, which have high levels of antioxidants, fiber, and vitamins; processed meats, which contain fatty acids; superfluous foods characterized by a high level of lipid content and/or simple sugars; and soft drinks, which have a high simple sugar content without nutrients. ${ }^{49}$
The school-based Educació en Alimentació (the EdAl study) ${ }^{50}$ program was designed to verify the sustainability of the benefits from a previous EdAl study by assessing the obesity-related outcomes and lifestyles of 13- to 15-year-old adolescents. The EdAl program was comprised of 12 educational intervention activities that were based on improving health-related habits such as nutritional food selection, hand washing, and avoiding sedentary behavior. $^{50}$

\section{Outcomes}

\section{Energy and nutrient intake}

Two studies reported higher energy, protein, and fat intake after the intervention compared to baseline. ${ }^{45,46}$ Despite the lack of positive changes in macronutrient intake, lower levels of saturated fat and sugar consumption were presented in the CAFAP cohort study. In another multidisciplinary intervention study, lower energy intake and macronutrient intake were reported after the dietary intervention (at 8 weeks) in both the usual care group and the intensive care group. ${ }^{47}$

\section{Consumption of fruits, vegetables, and dairy products}

Improvements in consumption of fruits and vegetables among the children and adolescents were reported in three of the multicomponent-approach intervention studies. ${ }^{46-49}$ Smith et al..$^{46}$ stated that perceived fruit consumption and vegetable consumption of the participants were higher after the dietary intervention. OjedaRodríguez et al. ${ }^{47}$ and Serra-Paya et al. ${ }^{49}$ presented higher levels of dairy product consumption as well as fruit and vegetable consump- 
tion after the intervention in both groups. Meanwhile, a 4-year follow-up study showed decreased consumption of dairy products, fruits, and fish among children and adolescents. ${ }^{50}$

\section{Unhealthy dietary behaviors}

Lower consumption levels of sugar-sweetened juices and soft drinks and sweet, superfluous foods (cookies, pastries, dairy-based desserts, and French fries, which contain high levels of lipids and/ or simple sugars) were shown after the dietary intervention in three of the preceding studies. ${ }^{46,47,49}$

\section{Body composition}

Most of the studies showed decreased BMI z-scores of obese children and adolescents after 6 weeks to 6 months for each of the intervention studies. Theme-based nutritional sessions, involving portion size and food groups, ${ }^{51}$ feelings of hunger and satisfaction, ${ }^{52}$ nutrition counseling and phone calls, ${ }^{53}$ nutrition education group sessions and leaflets for caregivers, ${ }^{54}$ healthful and balanced diet with fruits and vegetables, ${ }^{55}$ and healthy beverage intake and increased consumption of fruits, nuts, legumes, vegetables, fish, and dairy products ${ }^{50}$ were implemented in childhood obesity intervention studies (data not shown).

\section{EFFECTS OF INDIVIDUALIZED NUTRITIONAL MANAGEMENT ON CHILDHOOD OBESITY}

There are numerous risk factors for obesity in children and adolescents, and these factors interact with a high level of complexity. The nutritional care process model (NCP) ${ }^{56}$ (Fig. 1) could be adapted well to this complex task through dietitian-delivered lifestyle interventions. ${ }^{57}$ The Academy of Nutrition and Dietetics developed the NCP, a highly qualified systematic approach to care, by employing four interrelated steps: nutritional assessment, diagnosis, intervention, and monitoring/evaluation. There is a requirement for standardizing the NCP and increasing the quality and consistency of nutritional care by using the International Dietetics and Nutrition Terminology (IDNT). ${ }^{58,59}$ Previously, we developed a study protocol ${ }^{60}$ to manage the dietary problems of moderately to severely obese children and adolescents by adopting the NCP and IDNT. Three general domains - nutrition intake, nutrition clinical, and nutritional behavioral — were employed for nutritional diagnosis (Table 3). Nutrition diagnosis is the act of identifying a disease or condition from its signs and symptoms by a dietetics profession. An identified nutritional problem is summarized into a structured

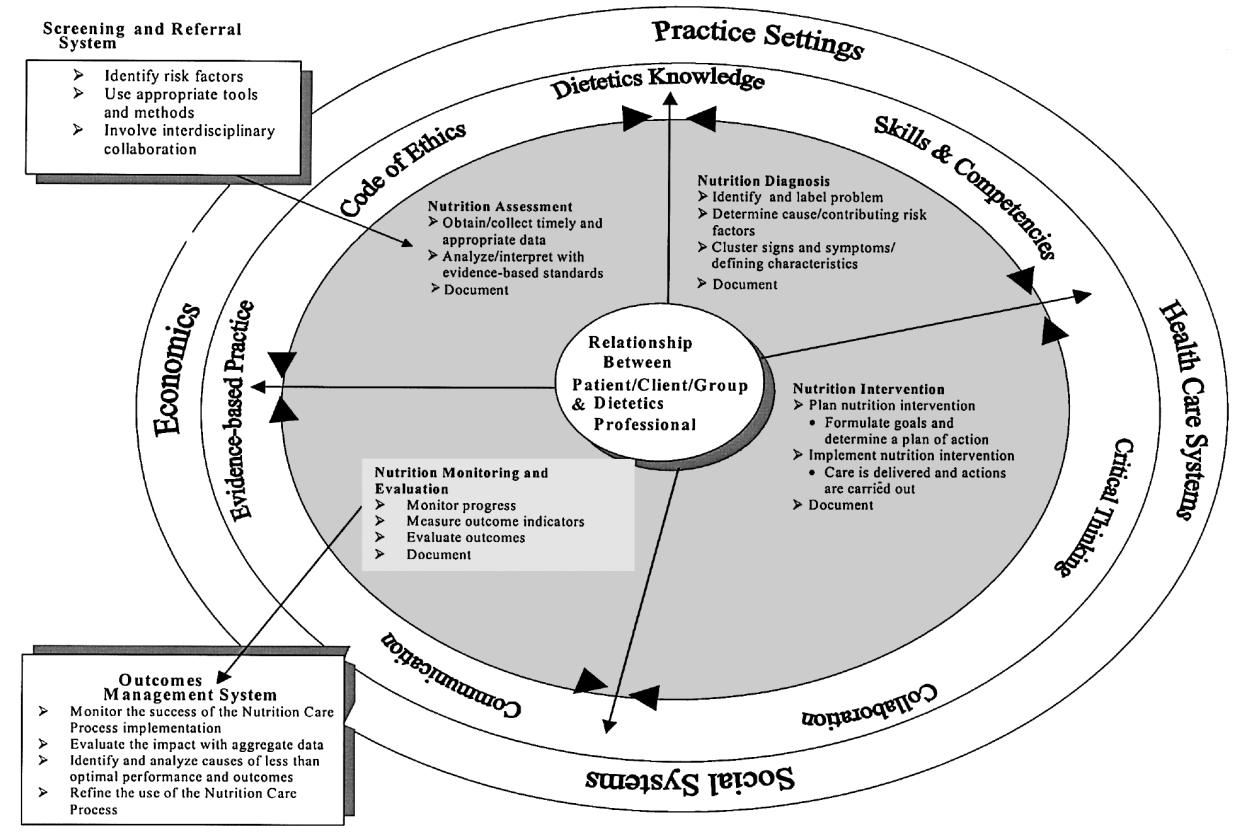

Figure 1. Nutrition Care Process and Model. Academy of Nutrition and Dietetics. Adapted from Lacey and Pritchett. J Am Diet Assoc 2003;103:1061-72, with permission from Elsevier. ${ }^{56}$ 
Table 3. Adoptable nutrition diagnosis of NCP components employed while using IDNT for childhood obesity

\begin{tabular}{|c|c|c|}
\hline Domain & IDNT & Nutrition diagnosis \\
\hline \multirow[t]{4}{*}{$\begin{array}{l}\text { Nutrition intake*: actual problems related to intake of } \\
\text { energy, nutrients through eating }\end{array}$} & Excessive energy intake & $\begin{array}{l}\text { Related to unwillingness in reducing intake as evidenced by excessive energy } \\
\text { intake compare with DRls }\end{array}$ \\
\hline & Excessive oral intake & $\begin{array}{l}\text { Related to lack of value for behaviour change or competing values as evidenced by } \\
\text { intake or overconsumption of energy-dense foods for meal (or snack) }\end{array}$ \\
\hline & Excessive fat intake & $\begin{array}{l}\text { Related to limited access to healthy food choice, as evidenced by frequent high-fat } \\
\text { food intake (or overconsumption) }\end{array}$ \\
\hline & Excessive carbohydrate intake & $\begin{array}{l}\text { Related to food and nutrition knowledge deficit as evidenced by FBG }>120 \mathrm{mg} / \mathrm{dL} \\
\text { or continuous carbohydrate overconsumption compared with DRls }\end{array}$ \\
\hline $\begin{array}{l}\text { Nutrition clinicalt: nutritional findings/problems identified } \\
\text { that relate to medical or physical conditions }\end{array}$ & Obesity & As evidenced by BMl for sex, age: $\geq 95$ th \%tile \\
\hline \multirow{5}{*}{$\begin{array}{l}\text { Nutrition behaviouralı: nutritional findings/problems } \\
\text { identified that related to knowledge, attitude/belief, } \\
\text { physical environments, access to food, or food safety }\end{array}$} & $\begin{array}{l}\text { Food- and nutrition-related } \\
\text { knowledge deficit }\end{array}$ & $\begin{array}{l}\text { Related to lack of prior exposure to accurate nutrition-related information, as } \\
\text { evidenced by deficit in food and nutrition-related recommendations knowledge }\end{array}$ \\
\hline & $\begin{array}{l}\text { Not ready for diet/lifestyle } \\
\text { change }\end{array}$ & $\begin{array}{l}\text { Related to denial of need to change, as evidenced by negative attitude and facial } \\
\text { expressions or failure to make a future visit }\end{array}$ \\
\hline & Self-monitoring deficit & $\begin{array}{l}\text { Related to unwillingness or disinterest in tracking progress, as evidenced by anger } \\
\text { or embarrassment about changes based on self-monitoring }\end{array}$ \\
\hline & $\begin{array}{l}\text { Limited adherence to } \\
\text { nutrition-related } \\
\text { recommendations }\end{array}$ & $\begin{array}{l}\text { Related to lack of value for behaviour change or competing values, as evidenced by } \\
\text { low or irregular compliance about planning }\end{array}$ \\
\hline & $\begin{array}{l}\text { Inability or lack of desire to } \\
\text { manage self-care }\end{array}$ & $\begin{array}{l}\text { Related to not being ready for diet/lifestyle change as evidenced by lack of } \\
\text { confidence about changes, based on self-monitoring record }\end{array}$ \\
\hline
\end{tabular}

*Defined as "actual problems related to intake of energy, nutrients, fluids, bioactive substances through oral diet or nutrition support"; ‘Defined as "nutritional findings/problems related to medical or physical conditions"; : Defined as "nutritional findings/problems that relate to knowledge, attitudes/beliefs, physical environment, access to food, or food safety." NCP, nutritional care process model; IDNT, International Dietetics and Nutrition Terminology; DRI, dietary reference intake; FBG, fasting blood glucose; BMI, body mass index.

sentence called a PES (Problem, Etiology, Symptom) statement. This statement is linked by the connecting terms problem/nutrition diagnosis related to etiology as evidenced by the signs and symptoms. The identified etiology, signs and symptoms point to a certain type of nutrition intervention and monitoring/evaluation that is needed. It is an important process in the implementation of a nutrition intervention and monitoring/evaluation of the NCP. A structured recommendation for nutritional management of childhood obesity was presented as a tool in another research study that helped practitioners structure their actions according to the four interrelated steps of the NCP model. This practice-based, evidenceinformed approach assisted not only the dietitians but also the professionals in pediatric obesity. The NCP four-step structured framework made it possible to structure patient-centered nutritional care and management of childhood obesity. ${ }^{61}$

\section{CONCLUSION}

Dietary intervention with a multisectoral approach has had posi- tive outcomes in modifying obesity-related dietary risk factors for obese children and adolescents. Excellent results from previous meta-analyses have reported a reduction in SSB intake and changes in body fatness, ${ }^{62}$ reduction in high-fat food and sugary beverages, increased intake of fruits and vegetables, reduction in snacks, and maintenance of a balanced diet. ${ }^{63}$

These positive changes were found immediately after the intervention; however, unfavorable outcomes were reported after longterm follow-up in terms of weight fluctuation, increased energy intake, macronutrient intake, and unhealthy dietary behaviors. Furthermore, it is hard to distinguish isolated impacts of nutrition care in childhood obesity because of the complex and interacting components of the multidisciplinary interventions. ${ }^{64}$ Behavioral modification and motivational interviewing on the health and diet of children and adolescents, to improve their self-control and mindful eating for sustainable healthy weight and nutritional status, are required to provide nutritional education and management.

From this viewpoint, evidence-based practice in dietary problem solving can suggest effective methods by considering behavioral 
and environmental risk factors in a diet and providing tailored nutritional therapy according to the stages of change among children and adolescents. In spite of these beneficial effects, we are facing barriers to providing this intervention due to the time and cost of developing more methods for countering childhood obesity. For this reason, individual, familial, social, and political-level involvement are recommended for effective and sustainable nutritional management of childhood obesity. In addition, practical key messages for health and diet may be helpful in establishing healthful habits and lifestyles in this public health crisis.

\section{CONFLICTS OF INTEREST}

The authors declare no conflict of interest.

\section{ACKNOWLEDGMENTS}

We thank Seran Choi and Nayoung Kim from Kyung Hee University for assisting with the review and identifying recent intervention studies.

\section{AUTHOR CONTRIBUTIONS}

Study concept and design: HL; analysis and interpretation of data: JK; drafting of the manuscript: all authors; critical revision of the manuscript: all authors; administrative, technical, or material support: JK; and study supervision: HL.

\section{REFERENCES}

1. Nishtar S, Gluckman P, Armstrong T. Ending childhood obesity: a time for action. Lancet 2016;387:825-7.

2. NCD Risk Factor Collaboration (NCD-RisC). Worldwide trends in body-mass index, underweight, overweight, and obesity from 1975 to 2016: a pooled analysis of 2416 populationbased measurement studies in 128.9 million children, adolescents, and adults. Lancet 2017;390:2627-42.

3. Ministry of Education. Report on student health checkup 2017. Sejong: Ministry of Education; 2018.

4. Sabin MA, Kiess W. Childhood obesity: current and novel ap- proaches. Best Pract Res Clin Endocrinol Metab 2015;29: 327-38.

5. Cruz ML, Goran MI. The metabolic syndrome in children and adolescents. Curr Diab Rep 2004;4:53-62.

6. Skinner AC, Perrin EM, Moss LA, Skelton JA. Cardiometabolic risks and severity of obesity in children and young adults. $\mathrm{N}$ Engl J Med 2015;373:1307-17.

7. Mikkilä V, Räsänen L, Raitakari OT, Marniemi J, Pietinen P, Rönnemaa T, et al. Major dietary patterns and cardiovascular risk factors from childhood to adulthood: the cardiovascular risk in young finns study. Br J Nutr 2007;98:218-25.

8. Ng M, Fleming T, Robinson M, Thomson B, Graetz N, Margono $\mathrm{C}$, et al. Global, regional, and national prevalence of overweight and obesity in children and adults during 1980-2013: a systematic analysis for the Global Burden of Disease Study 2013. Lancet 2014;384:766-81.

9. Eisenmann JC. Secular trends in variables associated with the metabolic syndrome of North American children and adolescents: a review and synthesis. Am J Hum Biol 2003;15:786-94.

10. Popkin BM, Adair LS, Ng SW. Global nutrition transition and the pandemic of obesity in developing countries. Nutr Rev 2012;70:3-21.

11. Executive Office of the Force WH. Solving the problem of childhood obesity within a generation: White House Task force report on childhood obesity report to the president. Washington (DC): Executive Office of the Force WH; 2010.

12. Taveras EM, Marshall R, Kleinman KP, Gillman MW, Hacker $\mathrm{K}$, Horan CM, et al. Comparative effectiveness of childhood obesity interventions in pediatric primary care: a cluster-randomized clinical trial. JAMA Pediatr 2015;169:535-42.

13. Gittelsohn J, Trude AC, Poirier L, Ross A, Ruggiero C, Schwendler $\mathrm{T}$, et al. The impact of a multi-level multi-component childhood obesity prevention intervention on healthy food availability, sales, and purchasing in a low-income urban area. Int J Environ Res Public Health 2017;14:E1371.

14. Dooyema CA, Belay B, Blanck HM. Implementation of multisetting interventions to address childhood obesity in diverse, lower-income communities: CDC's childhood obesity research demonstration projects. Prev Chronic Dis 2017;14:E140.

15. Ganter C, Aftosmes-Tobio A, Chuang E, Kwass JA, Land T, 
Davison KK, et al. Lessons learned by community stakeholders in the Massachusetts childhood obesity research demonstration (MA-CORD) project, 2013-2014. Prev Chronic Dis 2017;14:E08.

16. Ahrens W, Siani A, Adan R, De Henauw S, Eiben G, Gwozdz W, et al. Cohort profile: the transition from childhood to adolescence in European children-how I: family extends the IDEFICS cohort. Int J Epidemiol 2017;46:1394-5j.

17. World Health Organization. Diet, nutrition and the prevention of chronic diseases: report of the joint WHO/FAO expert consultation. WHO Technical Report Series 916. Geneva: World Health Organization; 2003.

18. Appannah G, Pot GK, Huang RC, Oddy WH, Beilin LJ, Mori TA, et al. Identification of a dietary pattern associated with greater cardiometabolic risk in adolescence. Nutr Metab Cardiovasc Dis 2015;25:643-50.

19. Baker JL, Farpour-Lambert NJ, Nowicka P, Pietrobelli A, Weiss R; Childhood Obesity Task Force of the European Association for the Study of Obesity. Evaluation of the overweight/obese child--practical tips for the primary health care provider: recommendations from the Childhood Obesity Task Force of the European Association for the Study of Obesity. Obes Facts 2010;3:131-7.

20. Shin SM. Association of meat intake with overweight and obesity among school-aged children and adolescents. J Obes Metab Syndr 2017;26:217-26.

21. Crowe TC, Fontaine HL, Gibbons CJ, Cameron-Smith D, Swinburn BA. Energy density of foods and beverages in the Australian food supply: influence of macronutrients and comparison to dietary intake. Eur J Clin Nutr 2004;58:1485-91.

22. Panagiotakos D, Pitsavos C, Chrysohoou C, Palliou K, Lentzas I, Skoumas I, et al. Dietary patterns and 5-year incidence of cardiovascular disease: a multivariate analysis of the ATTICA study. Nutr Metab Cardiovasc Dis 2009;19:253-63.

23. Kim JA, Kim SM, Lee JS, Oh HJ, Han JH, Song Y, et al. Dietary patterns and the metabolic syndrome in Korean adolescents: 2001 Korean National Health and Nutrition Survey. Diabetes Care 2007;30:1904-5.

24. Shin HJ, Cho E, Lee HJ, Fung TT, Rimm E, Rosner B, et al. Instant noodle intake and dietary patterns are associated with distinct cardiometabolic risk factors in Korea. J Nutr 2014; 144:1247-55.

25. Popkin BM, Gordon-Larsen P. The nutrition transition: worldwide obesity dynamics and their determinants. Int J Obes Relat Metab Disord 2004;28 Suppl 3:S2-9.

26. Han JC, Lawlor DA, Kimm SY. Childhood obesity. Lancet 2010; 375:1737-48.

27. Timlin MT, Pereira MA, Story M, Neumark-Sztainer D. Breakfast eating and weight change in a 5-year prospective analysis of adolescents: Project EAT (Eating Among Teens). Pediatrics 2008;121:e638-45.

28. Diethelm K, Huybrechts I, Moreno L, De Henauw S, Manios Y, Beghin L, et al. Nutrient intake of European adolescents: results of the HELENA (Healthy Lifestyle in Europe by Nutrition in Adolescence) Study. Public Health Nutr 2014;17:48697.

29. Hoppu U, Lehtisalo J, Tapanainen H, Pietinen P. Dietary habits and nutrient intake of Finnish adolescents. Public Health Nutr 2010;13:965-72.

30. Koo HC, Poh BK, Abd Talib R. The GReat-Child ${ }^{\mathrm{TM}}$ Trial: a quasi-experimental intervention on whole grains with healthy balanced diet to manage childhood obesity in Kuala Lumpur, Malaysia. Nutrients 2018;10:E156.

31. Papanikolaou Y, Jones JM, Fulgoni VL 3rd. Several grain dietary patterns are associated with better diet quality and improved shortfall nutrient intakes in US children and adolescents: a study focusing on the 2015-2020 Dietary Guidelines for Americans. Nutr J 2017;16:13.

32. Fitch A, Fox C, Bauerly K, Gross A, Heim C, Judge-Dietz J, et al. Prevention and management of obesity for children and adolescents [Internet]. Bloomington, Minnesota: Institute for Clinical Systems Improvement; 2013 [cited 2019 Nov 20]. Available from: https://jesse.tg/ngc-archive/summary/10019

33. Ministry of Health. Clinical guidelines for weight management in New Zealand children and young people. Wellington: Ministry of Health; 2016.

34. Wang Y, Lobstein T. Worldwide trends in childhood overweight and obesity. Int J Pediatr Obes 2006;1:11-25.

35. Matricciani L, Olds T, Petkov J. In search of lost sleep: secular trends in the sleep time of school-aged children and adolescents. 
Sleep Med Rev 2012;16:203-11.

36. Libuda L, Alexy U, Buyken AE, Sichert-Hellert W, Stehle P, Kersting M. Consumption of sugar-sweetened beverages and its association with nutrient intakes and diet quality in German children and adolescents. Br J Nutr 2009;101:1549-57.

37. Myszkowska-Ryciak J, Harton A, Lange E, Laskowski W, Gajewska D. Nutritional behaviors of polish adolescents: results of the wise nutrition-healthy generation project. Nutrients 2019;11:E1592.

38. Abreu S, Santos R, Moreira C, Vale S, Santos PC, Soares-Miranda $\mathrm{L}$, et al. Association between dairy product intake and abdominal obesity in Azorean adolescents. Eur J Clin Nutr 2012;66:830-5.

39. Academy of Nutrition and Dietetics. Pediatric weight management: major recommendations. Cleveland $(\mathrm{OH})$ : Academy of Nutrition and Dietetics; 2015.

40. Hoelscher DM, Kirk S, Ritchie L, Cunningham-Sabo L; Academy Positions Committee. Position of the Academy of Nutrition and Dietetics: interventions for the prevention and treatment of pediatric overweight and obesity. J Acad Nutr Diet 2013;113:1375-94.

41. Woolford SJ, Clark SJ, Strecher VJ, Resnicow K. Tailored mobile phone text messages as an adjunct to obesity treatment for adolescents. J Telemed Telecare 2010;16:458-61.

42. Appel LJ, Clark JM, Yeh HC, Wang NY, Coughlin JW, Daumit $\mathrm{G}$, et al. Comparative effectiveness of weight-loss interventions in clinical practice. N Engl J Med 2011;365:1959-68.

43. Fernández-Alvira JM, Bammann K, Eiben G, Hebestreit A, Kourides YA, Kovacs E, et al. Prospective associations between dietary patterns and body composition changes in European children: the IDEFICS study. Public Health Nutr 2017;20: 3257-65.

44. Dietz WH. Periods of risk in childhood for the development of adult obesity: what do we need to learn? J Nutr 1997;127: 1884S-1886S.

45. Amini M, Djazayery A, Majdzadeh R, Taghdisi MH, SadrzadehYeganeh H, Abdollahi Z, et al. A school-based intervention to reduce excess weight in overweight and obese primary school students. Biol Res Nurs 2016;18:531-40.

46. Smith KL, Kerr DA, Howie EK, Straker LM. Do overweight adolescents adhere to dietary intervention messages? Twelvemonth detailed dietary outcomes from curtin university's activity, food and attitudes program. Nutrients 2015;7:4363-82.

47. Ojeda-Rodríguez A, Zazpe I, Morell-Azanza L, Chueca MJ, Azcona-Sanjulian MC, Marti A. Improved diet quality and nutrient adequacy in children and adolescents with abdominal obesity after a lifestyle intervention. Nutrients 2018;10:E1500.

48. Kustiani AI, Madanijah S, Baliwati YF. Changes in fiber intake and body weight of multi-component intervention program among bogor obese children, Indonesia. Pak J Nutr 2015;14: 785-91.

49. Serra-Paya N, Ensenyat A, Castro-Viñuales I, Real J, SinfreuBergués X, Zapata A, et al. Effectiveness of a multi-component intervention for overweight and obese children (Nereu program): a randomized controlled trial. PLoS One 2015;10:e0144502.

50.Llauradó E, Tarro L, Moriña D, Aceves-Martins M, Giralt M, Solà R. Follow-up of a healthy lifestyle education program (the EdAl study): four years after cessation of randomized controlled trial intervention. BMC Public Health 2018;18:104.

51. Rodriguez-Ventura A, Parra-Solano A, Illescas-Zárate D, Hernández-Flores M, Paredes C, Flores-Cisneros C, et al. "Sacbe”, a comprehensive intervention to decrease body mass index in children with adiposity: a pilot study. Int J Environ Res Public Health 2018;15:E2010.

52. van der Baan-Slootweg O, Benninga MA, Beelen A, van der Palen J, Tamminga-Smeulders C, Tijssen JG, et al. Inpatient treatment of children and adolescents with severe obesity in the Netherlands: a randomized clinical trial. JAMA Pediatr 2014;168:807-14.

53. de Ferranti SD, Milliren CE, Denhoff ER, Quinn N, Osganian SK, Feldman HA, et al. Providing food to treat adolescents at risk for cardiovascular disease. Obesity (Silver Spring) 2015; 23:2109-17.

54. Hidayanty H, Bardosono S, Khusun H, Damayanti R, Kolopaking R. A social cognitive theory-based programme for eating patterns and sedentary activity among overweight adolescents in Makassar, South Sulawesi: a cluster randomised controlled trial. Asia Pac J Clin Nutr 2016;25(Suppl 1):S83-92.

55. Yli-Piipari S, Berg A, Laing EM, Hartzell DL, Parris KO, Udwadia J, et al. A twelve-week lifestyle program to improve car- 
diometabolic, behavioral, and psychological health in Hispanic children and adolescents. J Altern Complement Med 2018;24: 132-8.

56. Lacey K, Pritchett E. Nutrition Care Process and Model: ADA adopts road map to quality care and outcomes management. J Am Diet Assoc 2003;103:1061-72.

57. Spear BA, Barlow SE, Ervin C, Ludwig DS, Saelens BE, Schetzina KE, et al. Recommendations for treatment of child and adolescent overweight and obesity. Pediatrics 2007;120 Suppl 4:S254-88.

58. Swan WI, Vivanti A, Hakel-Smith NA, Hotson B, Orrevall Y, Trostler N, et al. Nutrition Care Process and Model update: toward realizing people-centered care and outcomes management. J Acad Nutr Diet 2017;117:2003-14.

59. Thompson KL, Davidson P, Swan WI, Hand RK, Rising C, Dunn AV, et al. Nutrition care process chains: the "missing link" between research and evidence-based practice. J Acad Nutr Diet 2015;115:1491-8.

60. Kim J, Kim YM, Jang HB, Lee HJ, Park SI, Park KH, et al. Ev- idence-based nutritional intervention protocol for Korean moderate-severe obese children and adolescents. Clin Nutr Res 2019;8:184-95.

61. Pfeifflé S, Pellegrino F, Kruseman M, Pijollet C, Volery M, Soguel $\mathrm{L}$, et al. Current recommendations for nutritional management of overweight and obesity in children and adolescents: a structured framework. Nutrients 2019;11:E362.

62. Avery A, Bostock L, McCullough F. A systematic review investigating interventions that can help reduce consumption of sugar-sweetened beverages in children leading to changes in body fatness. J Hum Nutr Diet 2015;28 Suppl 1:52-64.

63. Pamungkas RA, Chamroonsawasdi K. Home-based interventions to treat and prevent childhood obesity: a systematic review and meta-analysis. Behav Sci (Basel) 2019;9:E38.

64. Vanherle K, Werkman AM, Baete E, Barkmeijer A, Kolm A, Gast C, et al. Proposed standard model and consistent terminology for monitoring and outcome evaluation in different dietetic care settings: results from the EU-sponsored IMPECD project. Clin Nutr 2018;37(6 Pt A):2206-16. 